MAGDALENA LILIANA FIGURNIAK (Uniwersytet Opolski)

\author{
THE JOURNAL AND LETTERS \\ OF DANIEL NIKOLAUS CHODOWIECKI (1726-1801) \\ POLISH-GERMAN PRINTMAKER, ENGRAVER \\ AND PAINTER \\ EGO-DOCUMENTS AS AN EXAMPLE AND EXPRESSION \\ OF NATIONAL IDENTITY
}

\title{
1. INTRODUCTORY REMARKS
}

Daniel Nikolaus Chodowiecki was one of the most popular artists of the second half of the $18^{\text {th }}$ century. He was called the German Hogarth $^{1}$ and not without reason, as his output was marked by great realism often enriched with satire. Chodowiecki had no equal in the domain of contemporary graphics, and therefore many European literary works contained his decorative designs.

The figure of Chodowiecki is very interesting when evaluated in reference to a sense of national identity ${ }^{2}$. Discussions on the

${ }^{1}$ William Hogarth (1697-1764) was a popular English painter, printmaker, pictorial satirist, editorial cartoonist and engraver. His work ranged from realistic to comic portraiture. Knowledge of his work was very pervasive in the $18^{\text {th }} \mathrm{c}$. Satirical political illustrations in his style are quite often referred to as "Hogarthian".

2 Concept of national identity in $18^{\text {th }}$ century definitely requires more discussion in distinct article. 
artist's identity appeared in the post-war period and they have remained controversial among historians ${ }^{3}$. Looking at Chodowiecki's autobiographical notes, it may be possible to explain how the artist viewed himself. The number of sources and interpretations is high but their multilingual nature, among them the journal of a journey to Gdańsk and numerous examples of correspondence, may also cause difficulties. Did he feel attached to one country more than another? How did he perceive himself in comparison with others? How deep into the mind of the artist has research to push forward in order to answer these questions which have troubled many researchers?

This discussion will be an attempt to analyse the figure of Daniel Nikolaus Chodowiecki on the basis of the notes from his journal on the journey to Gdańsk and selected examples of correspondence with family and friends in the years 1736-1786. In 1773 the artist took a two-month journey to his native city, the result of which is a multi-page journal and an accompanying album which contains 108 drawings made in pen and ink which depict, with surprising accuracy, Prussian towns and villages as well as the bourgeois and patrician community of Gdańsk. This journal will constitute the basis for further consideration of the great graphic artist that Daniel Chodowiecki undoubtedly was, related to his self-perception and that of others. This work of art is of doubly precious significance to researchers of the history of Royal Prussia and Gdańsk in the final period of the First Repub-

${ }^{3}$ A. Kraushar, Daniel Chodowiecki. Jego sceny dziejowe polskie oraz wizerunki królów, wodzów, dygnitarzy, uczonych i typów ludowych polskich rytowany na schyłku XVIII wieku [Daniel Chodowiecki. Historical scenes, images of Polish kings, military commanders, officials, scholars and Polish folk types engraved at the end of the $18^{\text {th }}$ century], (1930); E.S. Kruszewski, Daniel Chodowiecki w skandynawskich leksykonach [Daniel Chodowiecki in Scandinavian lexicons], "Acta Cassubiana", 1 (1999), p. 361-367. 
lic, both as descriptions of the everyday reality surrounding the artist as well as to historians of art owing to the set of unique drawings. Unsurprisingly for many years it has been a subject of research and interest for academics. But before an analysis of Daniel Chodowiecki, I would like to present briefly the political situation of Gdańsk in the First Republic. Its situation in the second half of the $18^{\text {th }}$ century was not too bright. The First Republic had slowly begun to decline and with it the port city ${ }^{4}$. Some concerns were brought out by the 1756-1763 conflict, i.e. Seven Years' War, in which the Republic did not participate. Gdańsk however - due to its geographical position - was exposed to attacks by Russian and Prussian forces 5 . A more fundamental event that had a significant impact on the economy of this great port was the First Partition of Poland. The weak Republic that had not played a significant role on the international stage was not able to provide adequate protection for the city. The citizens of Gdańsk decided to take their fate into their own hands and started looking for business contacts with other European countries: the Netherlands, France, Russia and even England. Since the early 1770s, the citizens of Gdańsk were absorbed primarily by the threat of Prussian rule. However, they managed to avoid it, mainly due to Russia which did not allow the city to be taken over, at the same time refusing the idea of establishing a free city. Then Frederick the Great, King of Prussia, applied an economic blockade against Gdańsk, combined with a policy of harassment. He attacked the city using force and established customs points on all roads ${ }^{6}$. The wealthy social strata, especially Gdańsk merchants, acutely felt the

4 K. Piwowarski, Dzieje Gdańska w zarysie [The History of Gdańsk in outline], (1997), p. 160.

${ }^{5}$ Dzieje Gdańska [The History of Gdańsk], ed. by E. Cieślak, Cz. Biernat, (1975), p. 283.

6 S. Askenazy, Gdańsk a Polska [Gdańsk and Poland], (2001), p. 68. 
unstable position of the city. The Prussian authorities presented requests continuously, and applied various forms of administrative and customs harassment ${ }^{7}$. Prussian troops occupied Nowy Port, began to levy additional duty on cargo ships and carried out checks before the cargo could enter the old port which led to a reduction of trade in Gdańsk. When the city came under Prussian rule, there were radical changes in the economic and cultural life of the city. The invader introduced its own governmental and administrative system. Many urban cultural institutions were eliminated: a severe blow. However, despite these unfavourable conditions, art retained its former position ${ }^{8}$.

\section{THE FIGURE OF DANIEL NiKOLAUS CHODOWIECKI}

Daniel Chodowiecki was born on $16^{\text {th }}$ October 1726 in Gdańsk, from a family with Polish, French and German traditions. He was the son of a Gdańsk merchant, Gottfried Chodowiecki (16981740), and a French Huguenot, Marie Henriette Ayrer (17021779) ${ }^{9}$. The Chodowiecki family came from $\mathrm{Chocz}^{10}$, a small town near Gniezno in the old Kalisz district which for a long a time had belonged to dissenters. The Chodowiecki's had at first been Bohemian Brethren and later they joined the Lutheran church. It is

7 E. Cieślak, Charakterystyka okresu 1655-1815 [Characteristics of the period 1655-1815], in: Historia Gdańska, ed. by E. Cieślak, 3, 2: 1793-1815 (1993), p. 230-232.

8 E. Cieślak, Charakterystyka okresu 1655-1815, p. 206.

9 Daniel Chodowiecki. Briefwechsel zwischen ihm und seinen Zeitgenossen, ed. by Ch. Steinbrucker, (1919), p. 252.

10 Słownik geograficzny Królestwa Polskiego i innych krajów słowiańskich [Geographical Dictionary of the Kingdom of Poland and other Slavic countries], ed. by F. Sulimierski, B. Chlebowski, W. Walewski, 1 (1880), p. 602-603. 
certain that his father was of Polish descent ${ }^{11}$ while the surname would also indicate such a relation. Daniel's mother came from the French Huguenot emigration and most probably she arrived in Gdańsk with her family from Leipzig, due to religious persecution. Gdańsk was often considered an asylum for those from all over Europe who sought religious and political tolerance ${ }^{12}$. When the incredible potential of young Daniel's capabilities was observed, work to develop it started. At first he practiced his talent under the watchful eye of his father but, due to poor painting ability, was not able to help him much. The miniaturist, Justine Ayrer, who was Daniel's aunt on his mother's side, became his next artistic authority. Chodowiecki was constantly looking for a technique that would suit his abilities. He practiced drawing using a pencil and pastels, oil painting, and enamelling. Unfortunately, work in commerce, in which he still saw his future, competed with the desire to devote himself to art. Chodowiecki left his home town in his early youth and in 1743 he settled in Berlin to finalise his commercial studies, to which he had been prepared from his earliest years by his father. He stayed with his uncle, Antoine Ayrer ${ }^{13}$, like his brother Gottfried. This is how the Polish artistic community lost a precious illustrational talent and Berlin gained a superb artist, the future director of the Academy of Fine Arts. Quite a lot of time passed before Chodowiecki finally decided to abandon his merchant's profession and become an artist. His art and the multitude of orders for snuff and other boxes decorated

11 A. Boniecki, Herbarz Polski, Wiadomości historyczno-genealogiczne o rodach szlacheckich [Polish Heraldry, Historical and genealogical information on noble lineage], 1, 3 (1900), p. 34.

12 M. Bogucka, Migracje baltyckie a Gdańsk u progu ery nowożytnej (XVIXVIII) [Baltic Migrations and Gdańsk at the beginning of the modern period (16th-18th c.)], “Zapiski Historyczne”, 52 (1987), p. 79-94.

13 Daniel Chodowiecki. Briefwechsel zwischen, p. 25. 
with genre scenes led to his devotion to enamelling. However, he did not stop there; Chodowiecki specialised in all forms of painting. In Berlin he took drawing lessons in the workshop of Christian Bernhard Rode, the great historical painter. From 1756 he started to use the etching technique ${ }^{14}$, retouched using a graver and dry needle and ultimately specialised in engraving. The first engraving that we have is of the game of Wurfl (Passe-dix), signed by the pseudonym, Hucquier, most probably for fear of uncomplimentary criticism. With time, however, Chodowiecki achieved significant ability in this technique. The commercial success of the etching, based on his own oil painting, Calas' Farewell to the Family $^{15}$, led to the artist being appreciated by the publishing market. This work can be considered a masterpiece based on a remarkably accurate analysis of its subject. Following this he received numerous orders from booksellers, who decorated the title pages of books, pocket calendars and albums with his engravings by which they increased the interest in and popularity of

14 Etching: this term denotes a graphic technique (also a copy obtained using this technique), in which the carvings are created due to the activity of acid on the metal (usually copper) plate. The artist covers the plate with acid resistant varnish and then makes the drawing using a steel needle, revealing the metal, and next etches with acid, which can be a water solution of nitric acid (aqua fortis, hence the Polish akwaforta) or a solution containing other substances. The grooves, created in this way, during printing under a press (by imprinting the plate on paper), are filled with ink. A copper plate may be subjected to further processing or retouched and the obtained copies represent the subsequent stages (states) of the work's creation, (Historia sztuki 1000-2000 [History of Art 1000-2000], ed. by A. Merot, (1998), p. 516).

15 Jean Calas (1689-1762), a Protestant Merchant from Toulouse was a victim of religious fanaticism and thoughtless judicature. Blamed for murdering his older son Marc-Antoine because he intended to convert to Roman Catholicism, he was sentenced to death by the Parliament of Toulouse. His property was confiscated and his children were locked up in monasteries. 
these works. His work decorates publications including those by Johannes Ewald, Johann Caspar Lavater, Gotthold Ephraim Lessing, Salomon Gessner, Christian Furchtegott Gellert, Johannes Bernhard Basedow, Jean Jacques Rousseau, Johann Wolfgang Goethe and Friedrich Schiller ${ }^{16}$. Around 1764 Chodowiecki joined the circle of the Berlin Academy of the Arts. In 1797, when he already had a solid position and acclaim as a very talented illustrator and graphic artist, he was awarded the honourable post as academy's director. The award of this position was proof of his talent.

\section{THE JOURNAL OF A JOURNEY}

In 1773 , after thirty years absence, the artist set out on a sentimental journey to his home town of Gdańsk, to settle property matters and visit his family. At this time, Chodowiecki, as a sharp observer, described with his typical precision the entire journey from Berlin to Gdańsk and the details of his stay in his beloved city. The days of its greatness were already past, but it still remained an important port.

The journal was written in colloquial French and was devoid of literary aspiration. Its substantial value is the information it includes on the difficulties of horse-drawn travel, conditions in Pomeranian inns, the poverty of the Kashubian countryside, but above all on the customs and social life of $18^{\text {th }}$ century Gdańsk. Neither did he miss the wealth of the court of Primate Jan Ga-

16 Chodowiecki Ilustration zu den deutschen Klassikernn, ed. by D. Chodowiecki, P. Landau, (1914), p. 4; Kruszewski, Daniel Chodowiecki, p. 364; T. Grzybkowska, Artyści i patrycjusze Gdańska [Gdansk artists and patricians], (1996), p. 105. 
briel Podoski and the grandness of the residences of the Polish aristocracy and gentry. As an artist, Chodowiecki was interested in works of art, easily confirmed by the very large number of descriptions of paintings and sculptures. The drawings in the journal, which are among the most valuable in Chodowiecki's entire oeuvre, constitute a vivid and detailed recording of contemporary everyday life. They are a priceless document of the iconography, culture and mentality of Gdańsk, simultaneously demonstrating many valuable details connected with costume and custom.

The journal's original in French did not survive the test of time and we only know it in its German translation. The first edition comes from 1895 and is owed to Wolfgang von Oettingen ${ }^{17}$. Subsequent German editions appeared from Willibald Franke and Willie Geisemeier ${ }^{18}$. The Polish version appeared in 2002 thanks to Małgorzata Paszylka ${ }^{19}$ based on the Willibald Franke edition. Detailed research on Chodowiecki's correspondence was carried out at the beginning of the $20^{\text {th }}$ century by Charlotte Steinbruc$\operatorname{ker}^{20}$. Based on an analysis of these sources, some aspects of Chodowiecki's self-perception and his perception of the world around him can be seen and will be demonstrated below.

17 W. von Oettingen, Von Berlin nach Danzig. Eine Kunsterfahr im 1773 Jahre von Daniel Chodowiecki. 108 Lichtdrucke nach dem Originalen in der Konigl. Akademie der Kunste in Berlin, (1895).

18 W. Franke, Daniel Chodowieckis Kunstlerfahrt nach Danzig im Jahre 1773. Des Kunstler Tagebuch diser Reiss in deutscher ubertragung und Skizzenbuch in getreuer Nachbildung mit einer Einleitung, (1919); Daniel Chodowiecki. Die Reiss von Berlin nach Danzig, ed. by W. Geisemeier, 2 (1994).

19 Daniela Chodowieckiego dziennik z podróży do Gdańska z 1773 roku [Daniel Chodowiecki's journal of the journey to Gdańsk in the year 1773], ed. by M. Paszylka, (2002), p. 8.

20 Daniel Chodowiecki. Briefwechsel zwischen. 


\section{VARIETY OF CULTURE IN GDAŃSK}

In addition to his sketches during his two-month stay in Gdańsk in his family home at św. Ducha 54, Chodowiecki created a number of portraits of important people from the society elite. The artist's talent was quickly appreciated and therefore invitations to most noble houses in Gdańsk were often received. He had contact with the variety of cultures and opinions found in Gdańsk. Some of the opinions were noted in his journal and conclusions can be drawn based on them. Chodowiecki revealed many a time that Frederick the Great's order of things was close to his heart. He mentioned in his notes that he was outraged by criticism towards the Prussian king, although he would not show it, however he would not continue a political discussion if he disagreed with such opinions. This is exactly what happened during a talk with an Italian merchant, Francisco Brunatti, who spoke of Frederick the Great in an unfavourable manner in the company of Franciszek Gotfryd von Rottenburg. Chodowiecki preferred to stop this conversation as he thought it made no sense ${ }^{21}$. Another time the artist showed he would not stand by when insults were directed at his ruler, and during a conversation at Primate Jan Gabriel Podoski's residence he was outraged at Dr Wolff who was making fun of the King of Prussia in a coarse manner. The artist gave a blunt answer to a boorish statement in which the other said that he would prefer to be a pig than a subject of Frederick the Great. Chodowiecki made it clear that he preferred to be a subject of the king and would willingly ascribe the attributes of a pig to those who did not have the courage to do as he had done ${ }^{22}$. Judging from such behaviour it can be ascertained that Chodowiecki felt himself

21 Daniela Chodowieckiego dziennik, p. 19-20.

${ }^{22}$ Ibidem, p. 56. 
a faithful subject of the King of Prussia and not of the Republic. From the notes in his journal it can be seen that Chodowiecki was no stranger to politics ${ }^{23}$. In 1773, after the First Partition of Poland, $18^{\text {th }}$ September 1772, Gdańsk was still independent. In 1793 however did it find itself under Prussian occupation. Chodowiecki's stay in Gdańsk took place just after the First Partition, but despite this no expression of grief can be found in his journal on the fall of the Republic. The only mention which appeared is information on the ending of the 'Gdańsk affair' as a result of which the city became independent. Moreover, Chodowiecki in his discussion with Count Podoski, referred to the Republic in an indifferent way and it clearly appeared that Chodowiecki did not consider himself a Polish citizen. This is how he describes this exchange in his journal:

While we were painting, we talked about morality and politics but his knowledge of things which do not concern his own country seems to be rather small. Undoubtedly, he is not a royalist and he can see that if a Piast sat on the throne it would be a disaster for this country, as such a king would not have enough support to staff all the offices with his kindred and simultaneously close such careers to others ${ }^{24}$.

The artist was amazed by some Polish customs, although he respected them. In his journal he noted down a description of the scene where Countess Kunegunda Czacka was greeted by Ledóchowska, daughter of the starost, and a Miss Chrząszczewska. In the artist's opinion the whole situation had a slightly comic tint. The first of the ladies modestly kissed the countess on the hand, but the second kissed her hands many times with great enthusi-

\footnotetext{
${ }^{23}$ Ibidem, p. 49.

24 Ibidem.
} 
asm, attempted to kiss her patroness' knees about a dozen times, while she was being kissed on her nape. The ladies' farewell was exactly the same and underlined their social inequality. This is how the artist summed up the event:

I was about to ask the countess if this young lady gives away kisses to everyone she encounters in such a plentiful way, however I discarded this question, thinking it was some kind of religious ritual for them, and should not be mocked ${ }^{25}$.

However, Chodowiecki was outraged one day, when during his visit to a Mrs Gousseau he noticed when greeting a Dominican friar she kissed him on the hand. The woman explained that it was a widely accepted custom towards those in Catholic orders ${ }^{26}$. The event was also preserved in the form of a drawing which by accident fell into the hands of a Mrs Lauzakowska and finally became a subject of local gossip ${ }^{27}$. However, during the farewell to Primate Podoski, Chodowiecki, by Polish custom, kissed his hand and presented his compliments ${ }^{28}$.

\section{DRAWINGS}

It is not only the notes from the pages of his journal that constitute a document which presents an image of ethnic diversity in the eyes of Daniel Chodowiecki, his drawings during his stay in Gdańsk are also a valuable source. Among the 108 works there are those which demonstrate the multinational character of the city.

25 Ibidem, p. 37.

${ }^{26}$ Ibidem, p. 60.

27 Ibidem, p. 63.

28 Ibidem, p. 71. 
The artist depicted Gdańsk merchants from different countries of Western Europe, e.g. David Vernezobre from France and Francisco Brunati from Italy. Based on these drawings ${ }^{29}$ one can find out how the artist viewed the foreigners who had already settled in Gdańsk. Chodowiecki presented Brunati as a well-built man who gives an impression of self-confidence, which may be inferred from his facial expression and very dynamic attitude. He is presented in an interesting way through his hands. The right is raised with an open palm, while the left rests in his coat pocket. Analysing the pose in which the artist presented Brunati, one has the impression that he was energetic with an open manner. Chodowiecki probably had reasons to immortalise him in this natural way, in stressing his difference from the static and distinguished merchants and the German officials of his other drawings. His dress, originating from the vicinity of Milan, is an example of French-styled fashion. The man is wearing a luxurious robe a la française, which consists of a long coat, short jacket and breeches. On his head, there is a wig with a braid (the so-called queue) with a bow at the end. Dress itself does not distinguish Brunati from other men of similar social status. His ease of person combined with an energetic manner is unusual here. Chodowiecki also presented Vernezobre in a very realistic manner: in the drawing, the latter - instead of being in elegant dress - stands slightly hunched in a night gown and a night cap. The sharpness of observation of the artist and the multitude of detail demonstrated on the paper is astonishing, but one thing is puzzling. Why does he mention a 'young' Vernezobre ${ }^{30}$ in his diary, whereas we see

29 Original drawings from the journey to Gdańsk in 1773 are the property of Academy of the Arts in Berlin. Before they became the property of the Academy, they had belonged to Chodowiecki's family.

30 Daniela Chodowieckiego dziennik, p. 24. 
a much older man - one could even say a sick man - in the picture? The merchant who was a native of France was from the Huguenot minority in Gdańsk ${ }^{31}$, as was Chodowiecki's mother.

\section{MULTICULTURALISM}

Chodowiecki in his life had a great chance to get acquainted with the multiculturalism of Europe: at first, from the cosmopolitan city in which he was born and raised, and secondly throughout constant contact with the French minority in Berlin. Life in Gdańsk demanded adaptation to coexistence in a multinational bourgeois community where the meeting of ordinary citizens, merchants, and travellers from all over Europe was commonplace. In Berlin, the artist made use of his childhood experience. Chodowiecki was fluent in both French and German. He did not know Polish, although some of his works reveal a relationship with the Republic and at the same time showed a good knowledge of its history. There is even a list of works by Chodowiecki on Polish themes ${ }^{32}$. The inability to speak Polish is also proven by notes from the journal in which he described his farewell with the wife of the starost, Franciszek Antoni Ledóchowski. The artist mentioned that he used German and she used Polish and that is why they did not understand each other ${ }^{33}$.

$31 \mathrm{~K}$. Bem, The world is not big enough: the Vernezobre family in the refuge, "Proceedings of the Huguenot Society of Great Britain and Ireland", 28, 2, (2004), p. 189, available on the internet: http://archive.huguenotsociety.org. uk/108_Vol_XXVIII_Issue_2_2003-4.pdf (visited on 15.10.2012).

32 Daniel Chodowiecki, 64 reprodukcje [Daniel Chodowiecki, 64 reproductions], ed. by W. Zawadzki, A. Ryszkiewicz, (1953).

${ }^{33}$ Daniela Chodowieckiego dziennik, p. 69. 


\section{THE CORRESPONDENCE}

From numerous examples of Chodowiecki's correspondence with contemporaries from 1736-1786, it can be concluded that the language he used at home on a daily basis was French. This is revealed in Daniel's correspondence with his mother and her letters addressed to both her sons ${ }^{34}$. It is obvious that a part of his correspondence was written in German, for instance on matters related to the publishing business he corresponded a lot with poet and author Johann Caspar Lavater ${ }^{35}$, and with academic lecturers including Johann Georg Sulzer (1720-1779) and Ludwig von Beausobre (1730-1783). In French he corresponded with Jean Henry Samuel Formey $(1711-1797)^{36}$. He also wrote letters to artists, e.g. portrait-painter Anton Graff (1736-1813) and engraver Christian Gottlieb Geyser (1742-1803) ${ }^{37}$.

Undoubtedly, Chodowiecki felt only a slight relation with the Republic. He emphasized it himself in a letter to Duchess Christiana Hohenlohe-Kirschberg (née von Solm) in 1793 and in one of his letters from 1796 to Józef Łęski, a professor of the Jagiellonian University ${ }^{38}$. In fact the only thing that connected the artist with the Republic was Gdańsk where he had grown up and where he had left a part of his family. Mentally the artist was already a subject of the King of Prussia, most probably a result of the many years spent in Berlin.

\footnotetext{
34 Ibidem, p. 26-35.

35 Ibidem, p. 61-62.

36 Ibidem, p. 36, 40, 44.

37 Ibidem, p. 51, 278.

38 Kruszewski, Daniel Chodowiecki, p. 366.
} 


\section{THE "PAINTER OF SOULS"}

Chodowiecki worked until the later years of his life. He died on $7^{\text {th }}$ February or as other sources say $26^{\text {th }}$ October 1801 as a result of a fit of acute fever. His remains were buried at the French cemetery in Berlin (Dorotheenstädtischer Friedhof). It is not without reason that he was buried there. His wife, Jeanne Barez, whom he had married in 1755 and with whom he brought up several children, was of French descent similar to his mother. Moreover, Chodowiecki, throughout most of his life spent in Frederick's Berlin, maintained contacts with the French minority and the Huguenot church. He was an active member and involved in charity. A large number of his drawings were made within the community of the Berlin Huguenot society ${ }^{39}$.

Summarising Daniel Chodowiecki's work, one can see that it has a special place both in German and Polish history. Named by Władysław Prajer ${ }^{40}$ the "painter of souls" he went down in European history as one of the most famous and most notable graphic artists of the Enlightenment period. The applied term accentuates the artist's talent to show in his works a range of human emotions and feelings. The acuteness of this talented artist's observations continues to surprise viewers. Numerous works of Chodowiecki, which deal with everyday life, constitute a living picture of $18^{\text {th }}$ century Prussia ${ }^{41}$ with Berlin at the forefront. As a result of the

39 S. Badstübner-Gröger, Der Anteil Daniel Chodowiecki am Bildprogramm des Französischen Domes in Berlin in: Chodowiecki und die Kunst der Aufklärung in Polen und Preussen, ed. by H. Rother, A. Ryszkiewicz, (1986), p. 75.

${ }^{40}$ W. Prajer, Katalog rycin Daniela Chodowieckiego znajdujacych się w Muzeum Narodowym w Krakowie [Catalog of Daniel Chodowiecki's drawings from the National Museum in Cracow], (1905), p. 10.

41 Bilder aus der Brandenburg-Prussischen Geschichte Radierungen D. Chodowiecki, ed. by G. Voss, (1907). 
analysis of the journal of a journey to Gdańsk, the artist's standpoint on his national identity was revealed: it is possible that Chodowiecki felt himself, above all, as a subject of Frederick the Great, but this does not necessarily mean that he felt the relationship with the nation of Prussia. It should be noted that the relationship between Chodowiecki and the Huguenot Diaspora in Berlin and the relatively tolerant attitude of Frederick the Great in religious matters, could have a significant impact on the positive attitude of artist to the King of Prussia. Prussia was closer to his heart as he had spent most of his life there, established a family, and obtained a high state position. But his life was also related to the French minority in Berlin. Despite this modification, Chodowiecki was conscious of his relation with the Republic and above all with Gdańsk.

At present, Chodowiecki's works are enumerated at over four thousand drawings and around two thousand etchings of genre themes. They are kept in a number of European museums, e.g. in Poland, in the National Museums in Gdańsk, Kraków and Warsaw; in Denmark at the National Museum of Art in Copenhagen; and in Germany in the Berlin Academy of the Arts, the centre of his work. Many of his works are still kept in private collections all over the world. Some were lost during the turmoil of war or were destroyed. However, his art has survived in large part until today and constitutes precious historical material, very valuable for historians. 


\section{DZIENNIK I LISTY \\ DANIELA MIKOŁAJA CHODOWIECKIEGO (1726-1801), POLSKO-NIEMIECKIEGO GRAFIKA, RYTOWNIKA I MALARZA}

EGODOKUMENTY JAKO PRZYKŁAD WYRAŻANIA TOŻSAMOŚCI NARODOWEJ

(STRESZCZENIE)

W artykule omówiono twórczość autobiograficzną Daniela Chodowieckiego (1726-1801), jednego z najpopularniejszych europejskich artystów grafików drugiej połowy XVIII wieku. Urodzony w wielokulturowym Gdańsku, większość dorosłego życia spędził w Berlinie za czasów panowania Fryderyka II Wielkiego. Tam też pełnił funkcję dyrektora Akademii Sztuk, która działała wówczas jako organizacja zrzeszająca artystów i wspierająca rozwój sztuk pięknych. W pamięci potomnych utrwalił się jako bystry obserwator otaczającego świata, osoba o nieocenionym talencie ilustratorskim.

Artykuł jest próbą analizy biografii Chodowieckiego na podstawie zapisków w jego dzienniku z podróży do Gdańska w roku 1773 oraz wybranej korespondencji z rodziną i przyjaciółmi z lat 1736-1786. Został w nim szczegółowo omówiony życiorys artysty, począwszy od rozważań na temat jego francusko-polsko-niemieckiego pochodzenia, międzynarodowej kariery, skończywszy na informacjach na temat jego imponującej działalności artystycznej. Istotną cześć przyczynku stanowi również analiza zapisków samego dziennika oraz kilku wybranych, towarzyszących mu rysunków, pod kątem postrzegania przez artystę nie tylko siebie samego, ale też innych. Chodowiecki ze zdumiewającą dokładnością uwiecznił w swoich pracach gdańskie środowisko mieszczańskie i patrycjuszowskie, bardzo zróżnicowane w tym czasie etnicznie i kulturowo. Jego prace stanowią ciekawy obraz osiemnastowiecznej gdańskiej rzeczywistości. Odzwierciedlają ówczesne różnice w poglądach politycznych, czy zwyczajach. W artykule omówione zostały wybrane listy artysty, analizowane pod kątem języka, jakiego używał Chodowiecki w korespondencji prywatnej oraz $\mathrm{w}$ kontaktach związanych $\mathrm{z}$ interesami wydawniczymi.

Analiza dziennika oraz korespondencji Daniela Chodowieckiego pozwala na pewne przypuszczenia co do poczucia tożsamości narodowej artysty. Prusy były bliskie jego sercu. W tym kraju spędził większość swojego życia, założył rodzinę oraz odniósł niezwykły sukces. Nie zapomniał jednak o tym, skąd pochodził i gdzie przyszło mu się wychowywać, co znalazło wyraz w wielu pracach poświęconych tematyce polskiej.

Opracowane przez Autorkę / Bearbeitet von der Verfasserin / Prepared by the Author 


\section{TAGEBUCH UND KORRESPONDENZ VON DANIEL NIKOLAUS CHODOWIECKI (1726-1801), EINEM DEUTSCH-POLNISCHEN GRAFIKER, RADIERER UND MALER}

EGO-DOKUMENTE ALS BEISPIELHAFTER AUSDRUCK DER NATIONALEN IDENTITÄT

(ZUSAMMENFASSUNG)

Der Artikel beschreibt das autobiographische Schaffen von Daniel Chodowiecki (1726-1801), einem der beliebtesten europäischen Kunstgraphiker der zweiten Hälfte des 18. Jahrhunderts. Er wurde im multikulturellen Danzig geboren und verbrachte den größten Teil seines Erwachsenenlebens in Berlin während der Regierungszeit Friedrichs des Großen. Dort war er Leiter der Akademie der Künste, die damals eine Organisation von Künstlern mit der Aufgabe war, die Entwicklung der schönen Künste zu fördern und zu unterstützen. In dem Gedächtnis der Nachkommen ist er als aufmerksamer Beobachter und talentierter Darsteller der Umwelt verewigt.

Dieser Beitrag ist ein Versuch, die Biografie von Chodowiecki auf Grund der Aufzeichnungen in seinem Tagebuch über die Reise nach Danzig im Jahre 1773 und ausgewählter Korrespondenz mit seiner Familie und Freunden aus den Jahren 1736 bis $1786 \mathrm{zu}$ analysieren. So konnte detailliert die Biographie des Künstlers beschrieben werden, angefangen von seiner französisch-polnischdeutschen Herkunft und internationalen Karriere, bis zu Informationen über seine imponierende künstlerische Tätigkeit. Ein wichtiger Teil des Beitrages ist die Analyse der Tagebuchaufzeichnungen und einiger ausgewählter Zeichnungen, in Bezug auf die Selbst- und Fremdenwahrnehmung des Künstlers. Chodowiecki hat das ethnisch und kulturell vielfältige Bürger- und Patriziermilieu Danzigs mit erstaunlicher Genauigkeit in seinen Werken verewigt. Seine Werke stellen ein interessantes Bild der Stadt Danzig des 18. Jahrhunderts dar, sie spiegeln die Unterschiede der damaligen politischen Ansichten und Gewohnheiten wider. Der Artikel beschreibt die ausgewählten Briefe des Künstlers, in Bezug auf die Sprache, die er in privater und geschäftlicher Korrespondenz verwendet hat.

Die Analyse des Tagebuches und der Korrespondenz von Daniel Chodowiecki Danzig erlaubt einige Vermutungen zu nationaler Identität des Künstlers. Preußen war für ihn eine Herzensangelegenheit. In diesem Land verbrachte er den Großteil seines Lebens, gründete seine Familie und erzielte 
ungewöhnliche Erfolge. Er hat aber nicht vergessen, woher er kam und wo er erzogen worden war. Dies bleibt in seinen vielen Werken, die polnischen Themen gewidmet waren, immer erkennbar.

Tłumaczenie / Übersetzt von / Translated Renata Skowrońska

\section{SŁOWA KLUCZOWE / SCHLAGWORTE / KEYWORDS}

- świadomość narodowa; autobiografia; sztuka; kultura oświecenia; wielokulturowość Gdańska; Daniel Mikołaj Chodowiecki (1726-1801)

- Nationalbewusstsein; Autobiographie; Künst; Kultur der Aufklärung; Danzigs Multikulturalismus; Daniel Nikolaus Chodowiecki (1726-1801)

- national identity; autobiography; art; culture of Enlightenment; multiculturalism in Gdańsk; Daniel Nikolaus Chodowiecki (1726-1801)

\section{BIBLIOGRAFIA / BIBLIOGRAFIE / BIBLIOGRAPHY}

\section{ŹRÓDŁA DRUKOWANE / GEDRUCKTE QUELLEN / PRINTED SOURCES}

Daniel Chodowiecki. Briefwechsel zwischen ihm und seinen Zeitgenossen, ed. by Ch. Steinbrucker, (1919).

Daniel Chodowiecki. Die Reiss von Berlin nach Danzig, ed. by W. Geisemeier, 2 (1994).

Daniela Chodowieckiego dziennik z podróży do Gdańska z 1773 roku ed. by M. Paszylka, (2002).

Franke W., Daniel Chodowieckis Kunstlerfahrt nach Danzig im Jahre 1773. Des Kunstler Tagebuch diser Reiss in deutscher ubertragung und Skizzenbuch in getreuer Nachbildung mit einer Einleitung, (1919).

Oettingen W. v., Von Berlin nach Danzig. Eine Kunsterfahr im 1773 Jahre von Daniel Chodowiecki. 108 Lichtdrucke nach dem Originalen in der Konigl. Akademie der Kunste in Berlin, (1895). 


\section{LITERATURA / LITERATUR / LITERATURE}

Askenazy S., Gdańsk a Polska, (2001).

Badstübner-Gröger S., Der Anteil Daniel Chodowiecki am Bildprogramm des Französischen Domes in Berlin, in: Chodowiecki und die Kunst der Aufklärung in Polen und Preussen, ed. by H. Rother, A. Ryszkiewicz, (1986), p. 75-97.

Bem K., The world is not big enough: the Vernezobre family in the refuge, "Proceedings of the Huguenot Society of Great Britain and Ireland", 28, 2, (2004), p. 187-198.

Bilder aus der Brandenburg-Prussischen Geschichte Radierungen D. Chodowiecki, ed. by G. Voss, (1907).

Bogucka M., Migracje bałtyckie a Gdańsk u progu ery nowożytnej (XVI-XVIII), „Zapiski Historyczne”, 52 (1987), p. 79-94.

Boniecki A., Herbarz Polski, Wiadomości historyczno-genealogiczne o rodach szlacheckich, 1, 3 (1900).

Chodowiecki Ilustration zu den deutschen Klassikernn, ed. by D. Chodowiecki, P. Landau (1914).

Cieślak E., Charakterystyka okresu 1655-1815, in: Historia Gdańska, ed. by E. Cieślak, 3, 2: 1793-1815 (1993), p. 230-232.

Daniel Chodowiecki, 64 reprodukcje, ed. by W. Zawadzki, A. Ryszkiewicz, (1953). Dzieje Gdańska, ed. by E. Cieślak, Cz. Biernat, (1975).

Grzybkowska T., Artyści i patrycjusze Gdańska, (1996).

Historia sztuki 1000-2000, ed. by A. Merot, (1998).

Kraushar A., Daniel Chodowiecki. Jego sceny dziejowe polskie oraz wizerunki królów, wodzów, dygnitarzy, uczonych i typów ludowych polskich rytowany na schyłku XVIII wieku, (1930).

Kruszewski E.S., Daniel Chodowiecki w skandynawskich leksykonach, "Acta Cassubiana", 1 (1999), p. 361-367.

Piwowarski K., Dzieje Gdańska w zarysie, (1997).

Prajer W., Katalog rycin Daniela Chodowieckiego znajdujacych się w Muzeum Narodowym w Krakowie, (1905).

Słownik geograficzny Królestwa Polskiego i innych krajów słowiańskich, ed. by F. Sulimierski, B. Chlebowski, W. Walewski, 1 (1880). 